\title{
CMPK1 wt Allele
}

National Cancer Institute

\section{Source}

National Cancer Institute. CMPK1 wt Allele. NCI Thesaurus. Code C150215.

Human CMPK1 wild-type allele is located in the vicinity of $1 \mathrm{p} 33$ and is approximately $45 \mathrm{~kb}$ in length. This allele, which encodes UMP-CMP kinase protein, is involved in pyrimidine nucleoside monophosphate metabolism. 